\title{
Pot Chitra: the oldest audio-visual medium of Bengal and its' application in Fashion
}

\author{
${ }^{1}$ Najmul Kadir Kaikobad, ${ }^{2}$ Helena Nazneen Zobaida, ${ }^{3}$ Md Zafar Alam Bhuiyan, \\ ${ }^{I}$ Assistant Dean \& Center Head, Shanto-Mariam University of Creative Technology, City campus, Lalmatia, \\ Dhaka, Bangladesh \\ ${ }^{2}$ Coordinator \& Lecturer, Fundamental of Art \& Design, Shanto-Mariam University of Creative Technology, \\ City campus, Lalmatia, Dhaka, Bangladesh \\ ${ }^{3}$ Assistant Proctor \& Lecturer of Fashion Design, Shanto-Mariam University of Creative Technology, \\ City campus, Lalmatia, Dhaka, Bangladesh
}

\begin{abstract}
The paper attempts to study the importance of Art philosophy in the process of fashion designer. This goal could be extended to state that we intend to show the recognition of Folk Arts during all the developmental stages of Fashion Design. Folk Arts provide the proper understanding of the culture of a country and the nation. From that perspective, the Bengal Folk Arts are rich and diversely flourishing. Among the thousands of materials or objects in the Folk Arts it is not difficult to understand the stylish characteristics. The creations of art, its rhythmic outlines were attained by the artist's aesthetic mind. Therefore, the mass, volume and types of art-forms can be found, such as, pottery, carpentry and engraving, architecture, metal crafts, shell crafting, ivory crafting, mask making etc. The expression media of the Folk Arts, such as, clay, wood, tapestries, canvas, masks, graffiti, carpentry and wood carving, folk architecture, embroidery, cork-crafting, shell crafting, ornamentation, metal craft, basket weaving, even the fishing accessories. Pot Chitra, the traditional audio-video medium of Bengal, displays a rich vocabulary of motifs. These motifs are deeply rooted in strong religious beliefs and underlain a strong symbolism. Identifying Pot Chitra as formalized folklore, the word Pot Chitra has been analyzed. The scriptural customs of picture painting and the making of elongated Pot Chitra have been discussed. . Though there are many works about Pot Chitra but none has worked with it mingled with fashion. So, the work is pioneer ever in Bangladesh. The Pot Chitra was classified into the contexts. Some primitive processes of making brush and the ink exist which are very own of the Potua. The processes vary in different districts. In some cases there are some similarities as well.
\end{abstract}

Key Words: Pot Chitra: "Pot" means "scroll" and "Chitra" means Painting

- Potua: "Potua" or "Chitrakar" means "Painter".

- Tangail Hand Loom: One types of Bangladeshi Hand Loom

- Jamdanis: One types of Bangladeshi Hand Loom

- Chumki-ala: Name of Boutique Shop

- Gazi : Victor

- Gazir Pot: One types of Scroll Painting of South-West Bangle (Part of Bangladesh \& India)

- Kalighat Pot: One types of Scroll Painting of West Bengal (Province of India)

- Gayen: Lead singers or narrators of Scroll Painting

- Puranic: Mythological

- Pala Gaan: Live Drama

- Slokas: Mythological Folk stories

- Sabitri-Shottoban, Ram-Sita-Rabon and Korno: Characters from The Ramayan and The Mahabharat

- Sutrodhar: Carpenter

- Malakar: One type of Artisans who create handy crafts by using paper, one type of soft tree locally called 'Shola' etc.

\section{Introduction}

Pot Chitra is a kind of folk art. Fashion in Bangladesh is growing and becoming increasingly fruitful in its Endeavour's. Many designers are popular and making an effort to bring the industry up to international standards. In the process, however, it is sad to say that, in many cases, the glamour and glitter of other, more advanced industries around the world, such as India, influence our fusionist designers as so much that we often lose our own sense of fashion and merely follow the trends set by others. Being India as a neighboring country is hard for Bangladesh's self image. As it is, we tend to measure our success according to the success of the Indians, never taking into account that they are far older as a nation. In addition, we look to India for guidance in many different aspects of our daily lives, be it arts, music, entertainment or even fashion. Let's not be denied 
the fact that many Bangladeshi women and girls are quite happy trying to look like the latest Bollywood actress. In fact, how many times have one walked into a sari store and had a chumki-ala, shaded sari thrown in one direction, claiming it was the latest thing in India, even naming it after the movies in which beautiful doll-like actresses with impossibly thin figures wear. We constantly fall into the trap of idealising everything the Indians do. Those who can afford to do so always go to India for wedding shopping, rather than doing any major shopping in Bangladesh. There are already a handful of big stores in the Gulshan area which strongly resemble shops in India. Rather than taking pride in what sets us apart from other nations - our culture, our traditions and our heritage - we spend all our time copying Indian trends while we slowly lose our own sense of style. Gone are the days of Tangail Handloom and Jamdanis, because Bollywood has not thought them worthy of glamourising. Our designers have no choice but to keep bringing in more Indian trends in order to keep their clients happy. Our view as Researchers of Fashion Design is Bangladeshi fashion design deals only with the surface - block, batik, embroidery, hand paints - these aspects are very strong in the fashion industry, but unfortunately surface work is only a part of designing. There are many different aspects that are not touched upon as much as they should be here, such as fittings, patterns and also the relevance of what works with your surroundings. For example, many people don't recognise that the colours and fabrics that are relevant for summers - mainly light colours and fabrics that breathe - are not necessarily relevant for other seasons, such as winter, in which designer can use darker colours and more heavy fabrics. Using hand-woven fabrics that are both 'colorful and cultural,' we feel that we can create design such as depict the innocent and pure beauty of the indigenous community of Bangladesh.

\section{Literature Review}

For our research process we have chosen primary and secondary sources to collect the data. We have gone through many books like Banglar Lokoshilpo by Dr. P. Ghosh, Proshango: Pot, Potua o Potua Shangeet by Dr. C. Mayti, Gagir Gan: Shilpo Riti by A. Ahmed, Potua Roghu Nather Shilpo Bhubon by D. Hosson, Openti Bioscope by S. Shom, Bangalir Attoporichoy by Mustafa N. Islam, Banglar Lokonattao Palagan: Prokriti o Proyog by Raji. A. Alim, Foklor Shangrohosala by Shahed M. Sayed, Shanskritik Oaytijha Abong Nrittoshilpor Bistar by K. Lohani, Banglar Loko Shanskriti by W. Ahmed and other related books. More information was gathered from 'Openti Bioscope' where detailed description is given about Bangladeshi Folk Art like Pot Chitra. This book was very helpful in providing in depth explanations and references of other designers who will want to know the detail information about Pot Chitra. We have also visited few local boutique shops and design houses to survey and to understand the concept and visualize everything properly.

\section{Historical Context}

In Bengali, "Pot" means "scroll" and "Potua" or "Chitrakar" means "Painter". The origin of the painted scrolls is very ancient. We could find some in the Pharaohs' graves in Egypt. In India the first description of these painted scrolls can be found in a sacred text dated 200 B.C. Potua Art is of two kinds - art on broad sheet of folded cloth and eye-art on short piece of fabric. The fabric in fact makes the base for Pot Art. Clay, cowdung and some sticky elements are skillfully sprouted on the fabric. When dried, the fabric becomes tough but mellow enough for sustaining the stroke of the artist's brushes. Potua Artists draw on it religious motifs, such as Gods and Goddesses, Puranic stories, Slokas, etc. The pictures illustrate the religious and spiritual symbols the folk society likes. Kailas, Brindaban, Oudh and other holy places of the Hindus usually appeared in the Potua Art. This art form flourished particularly during the Buddhist period in Bengal. The Potua Art carried the life sketch of the Buddha and of his sayings and anecdotes. The Buddhist monks traded on Potua Arts very extensively. From the eighth century onward, the Potua tradition was taken over by the Hindus. Yadu, Yama, chandi, ten incarnates, deeds of Ramah, loves of Krishna, Gazi etc became the themes of Hindu Potua Art. A narrative type of folk painting is still being practised by a particular chitrakar (Painter) community in West Bengal (India) and in Bangladesh. Its origin is unknown. The origin of the chitrakar community too remains a matter of speculation.

\section{Pot Chitra In Bangladesh}

Besides this, another type of Pot Chitra of southeastern Bengal was classed Gazi's Pot Chitra. These were in practice around Birbhum region as well. As the Muslim Fakirs sometimes performed with this Pot Chitra, these were called Gazi's Pot Chitra. In fact, the Muslim Victors and the religious preachers are termed 'Gazi' as Victor. Various fantastic stories of Gazi's miraculous powers were painted on such Pot Chitra. Pot Chitra is found with a tiger-rider Gazi on the mission subjugating the tigers. In some regions of east-Bengal such as Mymensigh included the subjugation of tigers in Ponchokolyani Pot Chitra as well. But Gazi's Pot Chitra is not included in the West Bengali Ponchokolyani Pot Chitra.

A folk deity of the south-Bengal Boro Khan Gazi has attained a place in Gazi's Pot Chitra. He is prominent like the other established deities of the tigers, such as Dakshin Ray, Bonbibi etc. Both the Hindu and 
Muslim communities revere him. At some places figure of the Goddess Ganges is depicted within Gazi's Pot Chitra. The coordination of the worldly philosophies of the Hindu-Muslim communities has taken place on such. In Sylhet and Mymensingh the Potuai of Nagarchi Community still display Gazi's Pot Chitra. The Gazi's Pot Chitra of Jessore and Khulna were characteristically special.

\section{Pot Chitra In West Bengal}

The enlightened people of that time failed to identify the aesthetic sides of this Pot Chitra. Some have even disapproved of it. The social stratum the enlightened were parts of, the same stratum had been one of the targets that Kalighat Paintings had attacked. They considered the sarcasm similar to the vulgar literature. But at that time, the European archives set forth to collect these Pot Chitra. In 1917, poet Rudyard Kipling donated fifty pieces of very fine specimen of Kalighat Pot Chitra to the Victoria and Albert Museum of London. Actually these were done in Kolkata, but as it did not suit the choices of the educated, none here was inclined to showcase it. 150 specimens of Kalighat Pot Chitra recently came from the Deccan, on which the connoisseur wrote down his particulars in Tamil language. Victoria painting ideas were considered by the native educated people as the best painting culture. The, then immersed in westernization, mentalities did not value these Pot Chitra acceptable.

\section{SHE:}

\section{Present Context}

SHE (Self Help Enterprise) is a not-for-profit organization focused on women's welfare in rural parts of India, providing women with the training and support to produce exquisite Kantha pieces for people worldover. Kantha was used to sew several layers of old cotton tatters (using old handloom saris or dhotis) together to make quilts, centuries ago. Women created their own patterns inspired by the environment and the epics, and sewed these on to the wads, using their inherent artistry. What began here hundreds of years ago is today the fashion diktat world-over, thanks to the efforts of SHE. All proceeds from the sale of these items are put back into the welfare of the women and their families, who create these exquisite pieces through education and health care. Through its activities, SHE makes a difference in the lives of hundreds of rural woman in India, by providing them with the tools that give them financial independence.

\section{The SHE Collection}

Under the banner of Malika's Kantha Collection, SHE will now work towards a 'green' fashion. A new line of handcrafted clothes will soon be introduced which will be made from organic cotton using chemical free dye. Kantha has always believed in reuse and recycle; this will take it a step further.As such our latest addition to the vast range of MKC collection is patchwork Kantha, where patterns on textiles are created by using strips of Kantha fabrics, emulating the recycling concept of the era gone by. From bedspreads, throws, cushion covers, canopies and wall hangings to Kantha embellished shot silk lenhga-cholis, and silk sherwanis, there's a lot to choose from the SHE collection. (Website, sheindia, 2011).

\section{AARONG:}

Aarong is a chain of retail outlets located in the major cities of Bangladesh. It is an enterprise of BRAC, the largest non-governmental development organisation in the world. In the Bengali language, "Aarong" means a village fair. At present Aarong has 10 domestic outlets (6 in Dhaka 2 in Chattagong, 1 in Sylhet and 1 in Khulna), 1 franchise in London as well as considerable export operation in many European, North American and Asian countries. Aarong started its venture in 1978 and currently supports over 65,000 Bangladeshi artisans of whom 85 percent are women. Through a network of 647 productions, sub-centers and 13 production centers. Aarong works in collaboration with the Ayesha Abed Foundation, which provides the artisans the platform to exercise their expertise. Additionally, thousands of independent artisans, small entrepreneurs also earn their livelihood by marketing their craft products through Aarong. Aarong's mission is to help sustain rural craftsmanship and find a wider market for their products nationally and internationally. Aarong products include Nakshikantha, pottery, crafts on brass, jute, wood, candles, leather, hand woven cloth and silk products, jewelry and a wide variety of trendy yet indigenous products. The store specialties include Nakshikantha (a traditional form of embroidery rooted to the core of Bangladeshi village women) and Jamdani sarees. (website, aarong, 2010)

\section{RANG \& JATRA:}

RANG, one of the foremost boutique houses in Bangladesh is well-known for its colorful and particularly designed clothing of native craftsmen and artisan. The specialty of RANG is its exceptional and uniquely designed Sharee, Salwar kamiz, Fatua, Kurta, Shirt, T-shirt and other clothing. On any special occasion if anyone intends to buy anything extraordinary, the first name comes in his mind is RANG! At RANG 
we will find product on every and each occasion, it may be Eid, Puja, Nazrul Joyonti, Rabindra Joyonti, Pahela Falgun, Valentine's day, Boisakh (Bengoli New year), Amar Ekushey (21 February, International Mother Language Day), Friendship Day, Mother's day, Father's day and even season based product also available at RANG. We will find clothing of every possible color and shade and of different choices. (website, rang, 2009). Jatra, another exclusive fashion house working on boutiques, home décor and handicraft products with its unique design and modern presentation in Bangladesh, has been in operation for about seven years. Jatra uses local fabrics and traditional concepts of design. It mainly concentrates on a few specialized products and also has its own clothes manufacturing unit, block printing section and furniture manufacturing and finishing unit. Last year the team of Jatra, along with founder Anusheh Anadil, set up the goal to create a one-of-a-kind Eid collection that would be both unique and environment-friendly. After a year of work Jatra has become Bangladesh's first major fashion house to develop a whole line of fashion apparels and household items that uses recycled products, therefore creating an elegant and earth-friendly motif for Jatra's new Eid collection called the "Elements."

VII. Findings And Some Counter-Intuitive Results:

When starting up a research project one inevitably has presuppositions. Fortunately, some of these beliefs were met, but just as luckily there were also some unexpected findings.

\section{The main innovative strategy is to develop different approaches of Pot Chitra to Fashion Design.}

Fashions have multiple meanings and readings - variations that differ through time and space. Nevertheless, Fashions act as stabilisers of tradition through their institutional position. In the up to date fashion industry, all relationships are subjected to traditional culture like Bengal Pot Chita. A fashion designer should understand the visual arts in relation to history and cultures and reflecting upon and assessing the characteristics and merits of their work and the work of others.

2. The most successful Fashion Designer uses balanced elements such as line, colour, texture, form, shape etc. So as a Bangladeshi Fashion Designer we can inspire from Pot Chitra by using line, colour, texture, form, shape etc from it.

Fashion houses are involved in producing designs, but there is also the parallel production of ideas (fashion). There are different logics and specialties to these parallel processes, but they are related.

\section{Fashion designers can combine a traditional cultural focus with an important input of creativity.}

Numerous writers point to the importance of creativity as a vital input in the fashionable trends. Fashion is one of the cultural industries in Bangladesh, and this sector is often mentioned as the forerunner in the creatively driven by cultural tradition. So a fashion designer can understand and apply media, techniques and processes to Fashion Design by using knowledge of structures and foundations and choosing and evaluating a range of subject matters, symbols, and ideas. In this way, a fashion designer can make connections between visual arts and other disciplines.

\section{Bangladeshi fashion is not high tech - but nevertheless knowledge intensive.}

Fashion is not different from other industries in the contemporary economy with respect to its dependency on knowledge and information, but there are no objective, universal truths in fashion. Products depending on rapid changes in consumer fads sometimes change quickly. Sometimes, these trends are picked up without much alteration, while at other times one sees distinct local adjustments. Variations in the penetration of different fashion information (i.e. trends or styles or folk tradition), cannot simply be explained by placespecific characteristics such as cultural interest. Changing consumer demand in fashion reflects a relational contact between different modalities of information. Therefore, fashion knowledge might be best understood as a process based upon interpretation and comprehension of information. In aesthetic markets, knowledge must be related to contextual conditions.

\section{Space and specialties are important in the production of fashion.}

Fashion production has a multifaceted relationship with space and place and is produced both at local and global levels. The consistent use of outsourced production in the fashion industry, and the combination of different market logics and cultural emotions are signs of a genuinely globalised fashion industry. It is dispersed all over the world, and units in both developed and developing countries are tightly integrated. At the top, places play an important role in the transient activities associated with the aesthetic, cultural emotions and designbased innovation that is imperative in the production of fashion. In particular, certain urban districts function as contexts for fixed meanings; some places encourage the collective process of cultural production. 


\section{Niche marketing or targeted marketing is very common and growing in popularity.}

A favoured approach is to use ways of communication addressed to the individual consumer, such as buzz marketing, blogs, product placement and anything that can be construed as viral marketing. This has almost reached an omnipresent status. Simply telling consumers that something is in fashion through traditional mass marketing will not make it so. In an overcrowded marketing landscape, firms or electronic media have to come up with creative and innovative marketing tools to be noticed. Therefore, firms or electronic media increasingly seek to tap into marketing through person-to-person communication. Marketing is considered successful if the clothes are seen on the right people in the right settings. This can be done through showing clothes on users which attract attention, such as celebrities, but also by ensuring that the clothes are seen in the 'right' settings, such as popular places or restaurants. Marketing is thus driven by a selected group of empowered consumers.

\section{Consumers cultural tradition is important in the production of fashion.}

Fashion is a result of the conscious work by economic actors to try to shape our consumption patterns, but also of individual consumers' conscious fashion choices. One particular group of well-informed fashion consumers are people with high fashion capital. These are important in launching new brands, directing trends and deciding new looks. Fashion is thus not produced by corporate forces alone, but is socially negotiated through reciprocal, socially embedded processes.

\section{Conclusion}

Our curiosity knows no bound about Pot, Potua and Pot Music. Once Potua with a pot bag on the back of the shoulder used to visit houses and showing their pot started to sing to cool down the mind of the listeners. It was full of many charming histories of Ramayan, Mahabharat and Monsha and so on. The pot story thus created an enchanting lovely atmosphere of many romantic characters like, Sabitri-Shottoban, Ram-Sita-Rabon ,Korno and the mighty power Gazir gaan. From the birth of painting, we see that the artists were not related within a single profession. Rather, it was seen that they used to lead their life with multi professions. Thus they are very common people different ordinary professions. Sometimes snake charmers, carpenters, painters, farmers, Sutrodhar, Malakar, doll artists, technicians and mechanics, cobbler driver even rickshaw puller. But happiness never came to their life. Want and depression were common phenomenon of their life. Most of the Potua have left these professions that made them depressed, angry and hungry. Many have decided to leave it. But some of them who were optimist didn't loss hope, rather started to dream for better future and hence started to more in slow race to face the life. Pot Chitra and Pot Music are the arts for the rural people of Bangle which are taken by the people for their livelihood by there own choice and they are the artists for their professions only. We think, if Pot Chtra can be made globalize mingled with fashion, the Pot Chitra will be considered as a new dimension for fashion in the world and the artists will be honored and further development will be happened in the fashion world with the development of the artists.

Books:

[1] Ahmed. W. (2001) Banglar Loko Shanskriti, Goti Dhara, Dhaka.

[2] Ahmed. A. (1998) Gagir Gan: Shilpo Riti, Bangla Academy, Dhaka

[3] Ghosh. P. Dr. (2004) Banglar Lokoshilpo, Okkhor Binnash, Dhaka.

[4] Guptto. S. Shankor (2010) Banglar Mukh Ami Dekhiashi, Bornaon, Dhaka.

[5] Hosson. D. (2009) Potua Roghu Nather Shilpo Bhubon, Bornaon, Dhaka.

[6] Islam. N. Mustafa (2001) Bangalir Attoporichoy, Bornaon, Dhaka.

[7] Islam. K. Dr. Prof. (2012) Adhunik Bangla Kobitar Loko Shongskritir Shorup Anneshon, Pranto Prokasion, Dhaka

[8] Jhahan. A. Jahangir. (2012) Loko Vashar Suluk Shandhan, Shikha Prokashoni, Dhaka.

[9] Jhahan. A. Jahangir. (2011) Shangskar Lokachar Lokobishawsh, Mukto Chinta Prokashona, Dhaka.

[10] Lohani. K. (2010), Shanskritik Oaytijha Abong Nrittoshilpor Bistar, Ittadi, Dhaka.

[11] Morshed. M. Abul Kalam. (2011) Noboborsha o Banglar Loko Shongskritir, Shuci Potro, Dhaka.

[12] Moniruzzaman. Md. (2012) Bangladesher Itihash o Oitijha, Mizan Publisher, Dhaka.

[13] Mayti. C. Dr. (2001) Proshango: Pot, Potua o Potua Shangeet, Shahitto Lok, Calcutta.

[14] Phathan. M. Habibulla. (2012) Bangla probader Loko Kahini, Anindo Prokash, Dhaka.

[15] Raji. A. Alim (2010) Banglar Lokonattao Palagan: Prokriti o Proyog, Bangla Academy, Dhaka.

[16] Shom. S. (1993) Openti Bioscope, Camp, Calcutta

[17] Shahed M. Sayed (2010) Foklor Shangrohosala, Bangla Academy, Dhaka.

\section{Electronics Media:}

[1] Alpo Shalpo Golpo (2010), Episode 3, Subject: Gagir Pot, Duration: 14 Minutes 23 Second, Telecast: Desh TV.,Bangladesh 